\title{
Impacts on Productivity through Sustainable Fertilization of Nopal (Opuntia Ficus-Indica) Crops Using Organic Compost
}

\author{
Maria Elena Tavera-Cortés ${ }^{1}$, Pablo Emilio Escamilla-García ${ }^{2}$ \& Francisco Pérez-Soto ${ }^{2}$ \\ ${ }^{1}$ Instituto Politécnico Nacional, México City, México \\ ${ }^{2}$ Universidad Autónoma Chapingo, State of México, México \\ Correspondence: Pablo Emilio Escamilla-García, Division of Economic-Administrative Sciences, Universidad \\ Autónoma Chapingo, Km. 38.5, Carretera México-Texcoco, 56227, Texcoco de Mora, State of Mexico, Mexico. \\ Tel: 52-595-952-1500 Ext. 5494. E-mail: peeg@gmail.com
}

Received: January 15, 2018

doi:10.5539/jas.v10n4p297
Accepted: February 17, $2018 \quad$ Online Published: March 15, 2018

URL: https://doi.org/10.5539/jas.v10n4p297

\begin{abstract}
This paper shows the results obtained when evaluating current practices in cultivation processes of nopal. Production of nopal in the borough of Milpa Alta in Mexico City has been based for more than 40 years on the use of high doses of fresh cow manure (up to $600 \mathrm{t} \mathrm{ha}^{-1}$ ). It is necessary to consider the effects that this type of fertilization could have on the environment. In order to compare the effect of different fertilization methods on the production, quality and shelf-life of cladodes, three-year-old cactus plants were fertilized with compost, compost leachate, fresh manure cow and synthetic fertilizer; plants treated with water served as a control. The plants fertilized with compost (leached or solid) tended to a higher yield (g) per plant, although there were no significant statistical differences between treatments. Cladodes produced with solid compost or fresh manure showed a lower $\mathrm{pH}$ (4.7) than those produced with water to the soil. Cladodes produced with synthetic fertilizers showed higher shear strength than those produced with manure. Cladodes produced with synthetic fertilizer and compost leachate took more days to show shelf darkening (oxidation) than those produced with soil water. In addition, the use of compost showed a significant impact on cost reduction during the production nopal given a lower cost against manure and synthetic fertilizer.
\end{abstract}

Keywords: compost, organic fertilizer, nopal

\section{Introduction}

\subsection{The Borough of Milpa Alta and the Cultivation of Nopal}

Milpa Alta is the main producer of nopal (Opuntia Ficus-Indica) in Mexico, with a total of $30 \%$ of the national production. Figure 1 shows the production area of nopal in Mexico City. As can be seen, Milpa Alta stands out as the main producer, allocating $97.4 \%$ of its total area of cultivation. Consequently, all economic activity and business is closely linked with the cultivation of nopal. The small companies established in the area focused their activities on the planting, harvesting, cutting, packaging, transport, distribution and sale of nopal.

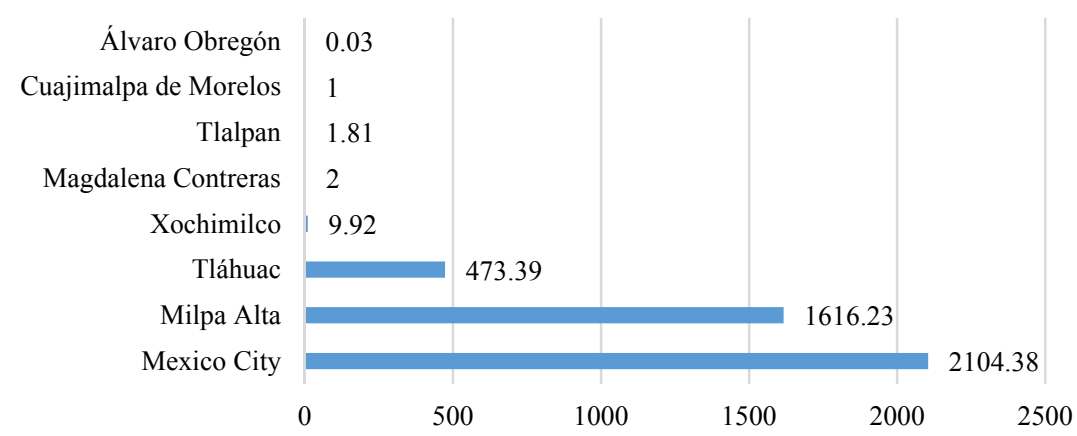

Source: GCDMX (2013).

Figure 1. Area of nopal production per borough (Ha) 


\subsection{Problems in the Production of Nopal}

The nopal market in Mexico is a factor that lacks stability due to harvest times and production is severely affected by climatic conditions. In addition, the loss of competitiveness in the production of nopal in Milpa Alta is due to: 1) High production costs, including the cost of the chemical fertilizer used by growing the crop; the cost of the pesticides used to combat the various pests that during the year afflict the cactus, which, although occasionally sprayed only once a year, also represent a high cost to the producer; the costs of distributing the product; and the payment of manual labor involved. 2) Low selling prices: There is a direct relationship between the production of the nopal and its price. Thus, the more produced, the lower its price should be, as shown in Figure 2, where it is observed that there is an opposite curvature that opens a gap between production and price, resulting in one of the problems that make up this problematic situation of the nopal producers. This gap responds to several aspects, however the variation is given mainly by negative impacts of weather conditions. Producers in Milpa Alta base their productions processes in an opencast model, therefore, climactic issues including heavy rains, frosts and floods can damage severely the crops, therefore prices in the market responds to this situation.

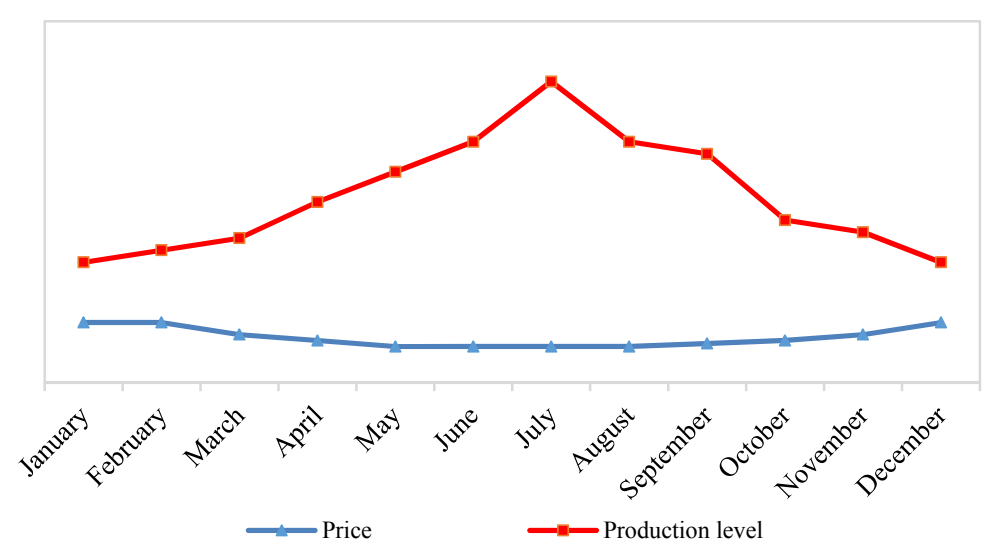

Figure 2. Price behavior of the nopal according to production levels

Source: Bunge-Vivier (2008).

3) Low yields: The two previous problems impact on the economic situation and the prices offered by the producers of nopal to place their product, as already observed, which contributes to a devaluation of the work of producers. 4) High levels of waste: The average annual production of nopal in Mexico is 842,162 tons (Velasco, 2014), the waste that amounts to 190,000 tons, is equivalent to a $23 \%$ waste of the product, in contrast the percentage of production destined for export is only $0.02 \%$ (INECC, 2009). 5) Deterioration of the environment: due to the high degree of use of chemical fertilizers, which causes pollution by pesticides and create a transgenic product. 6) Problems to the health of the community in general: This is caused by the concentration of chemical agents in the final crop that damages the health of the people. 7) Traditional crops: The nopal is still cultivated in the traditional way since the 1940s, which carries a risk for production. 8) Seasonality: having varying weather conditions and dealing with problems of pest proliferation and contamination of chemical agents (Hernandez-Cruz, 2016). 9) Chemical fertilization: this deteriorates soil, water and air. 10) Climate change potential: Directly related to the emission of methane gas $\left(\mathrm{CH}_{4}\right)$, which makes up $18 \%$ of the total emission of greenhouse gas that comes from $60 \%$ of human sources, such as agriculture and remains in the atmosphere for 12 years (WMO, 2013). 11) Lack of business vision: Producers lacks entrepreneur visions, which would lead them to increase opportunities of growth.

\subsection{The Cultivation and Fertilization of Nopal in Milpa Alta}

The production of nopal vegetables in the borough of Milpa Alta in Mexico City has historically been based on high doses of fresh manure with advantages for plant nutrition, soil physicochemical characteristics, moisture retention and weed reduction; however, it is also necessary to consider the disadvantages that this practice might have and offer fertilization alternatives. 
The application of manures in agriculture has advantages already known but it is also necessary to consider their possible environmental disadvantages. Compared to the application of chemical fertilizers, the application of manures to agricultural soils increases organic carbon and minerals such as nitrogen $(\mathrm{N})$, phosphorus $(\mathrm{P})$ and potassium $(\mathrm{K})$, improves $\mathrm{pH}$, increases microbial mass, increases the enzymatic activity making available to the $\mathrm{N}$ and $\mathrm{P}$ plants, as well as increasing the formation and stability of aggregates (Zhong et al., 2010; Acosta-Martínez et al., 2011; Karami et al., 2012) however, the application of high doses of manures in Milpa Alta could also lead to problems of high concentrations of organic matter and eutrophication in the waters of the lakes of the Valley of Mexico (Chanduví, 1993; Withers et al., 2014). This is in addition to the high probability of greenhouse gas $(\mathrm{GHG})$ emissions such as methane $\left(\mathrm{CH}_{4}\right)$ and nitrous oxide $\left(\mathrm{N}_{2} \mathrm{O}\right)$ and nitrate leaching $\left(\mathrm{NO}_{3}\right)$ in groundwater (Massé et al., 2003; Martínez et al., 2003; Kariyapperuma et al., 2012).

The use of compost could be considered as an environmentally friendly alternative in the production of nopal verdura in Milpa Alta. Manure composting may result in lower GHG emissions compared to their storage (Chen et al., 2014), while the application of compost to the soil could reduce $\mathrm{NO}_{3}$ and $\mathrm{PO}_{4}$ content in runoff and reduce GHG emissions as compared to manure, without losing the soil and crop advantages previously mentioned for the application of manures (Lynch et al., 2005; Kariyapperuma et al., 2012).

To consider the use of compost as a viable option to replace fresh cow manure in the production of nopal in Milpa Alta requires information from the objective comparison between this type of fertilization and other mineral sources. This is an exploratory research whose objective is to compare the effect of fertilization with fresh and composted cow manure on the yield, quality and life-shelf of nopal produced in field conditions in the rural area of Milpa Alta.

\section{Method}

This research applied a methodology based on an experimental design model. This method involves a are classical statistical model whose objective was to determine if certain factors influence a variable of interest, particularly the effect that different fertilization treatments have on crops. Therefore, the experiment considered as a first stage the obtaining of organic fertilizers.

\subsection{Production of Organic Fertilizer}

During a period of four months, organic fertilizer (compost) was made with fresh cow manure, prickly pruning residues and gardening residues (grass and eucalyptus wood) in a 2:2:1 ratio based on weight. Composting was done on a concrete bed with a slope of five degrees. The stack was $1.2 \times 1.0 \times 12 \mathrm{~m}$ (high, wide and long) and was aerated by flipping once a week; the temperature of the environment and the pile were recorded during composting process (Figure 1) and leachate was collected. At the end of the composting process, both compost and leachate (Tables 1 and 2) were analyzed, stored and stored for later use.

Table 1. Characteristics of the compost used in the experiment

\begin{tabular}{llll}
\hline Organic material (\%) & Nitrogen (\%) & Organic carbon (\%) & Relation C:N \\
\hline 49.2 & 1.12 & 28.54 & 25.5 \\
\hline
\end{tabular}

Source: Field work log.

Table 1 shows the results obtained after analyzing the chemical characteristics of the compost produced. It can be observed that figures present levels ranging in values that suit to values described in the literature. An organic fertilizer (compost) that is intended to cultivation of crops has to present a relation 1/30 (Nitrogen/Carbon). This implies that the compost produced for the experiment represents a value that can be consider acceptable as an harmless and sustainable fertilizer. In the same way, the analysis of leachate (Table 2) reported adequate values to be used in cultivation of consumption crops. It should be noted that both aspects provide basis for a sustainable model. The quality of the compost used in the cultivation process is directly linked to sustainable practices inasmuch as the process avoids negative affectations to the environment and seeks the control of natural resources. 
Table 2. Characteristics of the leachate used in the experiment

\begin{tabular}{lllllll}
\hline \multicolumn{5}{c}{ Minerals $\left(\mathrm{mg} \mathrm{L}^{-1}\right)$} & $\mathrm{pH}$ & $\begin{array}{l}\text { Conductivity } \\
\left(\mathrm{mS} \mathrm{cm}^{-1}\right)\end{array}$ \\
\hline Nitrates & Phosphorus & Potassium & Magnesium & Calcium & 5.5 & 5.83 \\
\hline
\end{tabular}

Source: Field work log.

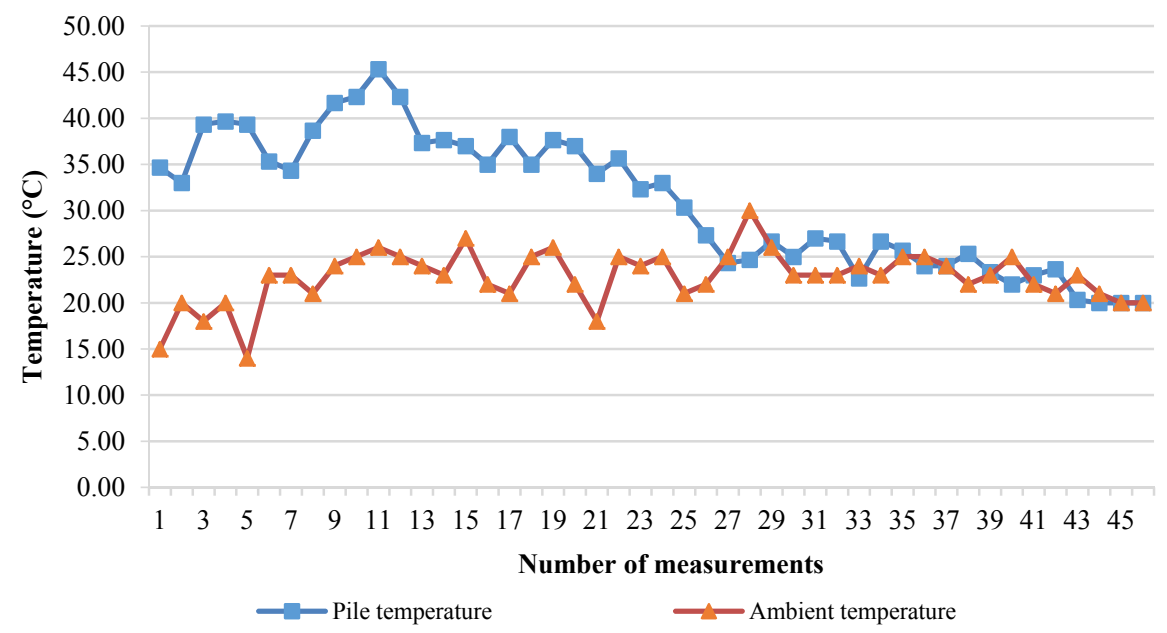

Figure 3. Process temperatures during compost production

Source: Field work log.

Figure 3 presents the behavior of temperatures during the production of the compost used in the experiment. It must be mentioned that the control of temperatures is a key element during the production process given the necessity of eradication of pathogens, which guarantee the harmlessness of the fertilizer.

\subsection{Evaluation of Fertilization Treatments}

The experiment was established in commercial nopal vegetable area in the town of San Lorenzo Tlacoyucan of the borough delegation of Milpa Alta in Mexico City (LN 1909'53", LW 99 02'44"). The orchards are designed in rows with distances of $1.0 \mathrm{~m}$ between rows and $50 \mathrm{~cm}$ between plants; the plants were composed of three to four structural plagues. Seven treatments were considered:

Table 3. Average levels of treatment applications

\begin{tabular}{ll}
\hline Treatment & Proportions \\
\hline T1: Regular water to soil (20 liters per row) & 20 liters \\
T2: Regular water & 20 liters \\
T3: Leached to soil (4 liters per row) & 4 liters \\
T4: Leachate from compost & 4 liters \\
T5: Chemical fertilizer $(250-50-200)$ & $10.8-13.2 \mathrm{~kg}$ \\
T6: Compost & $12.6-19.2 \mathrm{~kg}$ \\
T7: Fresh cow manure $\left(600 \mathrm{tha}^{-1}\right)$ & $31.8-38.4 \mathrm{~kg}$ \\
\hline
\end{tabular}

Note. Proportions represent average levels considering repetitions of application from 1 to 6.

Source: Field work log.

Compost and fresh manure were applied only once during the entire experiment, distributing in the rows (between two rows of nopal); the chemical fertilizer was applied during two consecutive years, dividing in two annual applications, one on April (125-50-100) and another in August of each year (125-00-100); the leachate obtained during the composting was diluted with regular water in a ratio of 20: 1 and applied monthly, sprayed to 
the plant until drop formation and in the soil at a dose of $2.0 \mathrm{~L}$ of diluted per linear meter in the row of plants. The application of water to the soil was done in a similar way to the application of leachate.

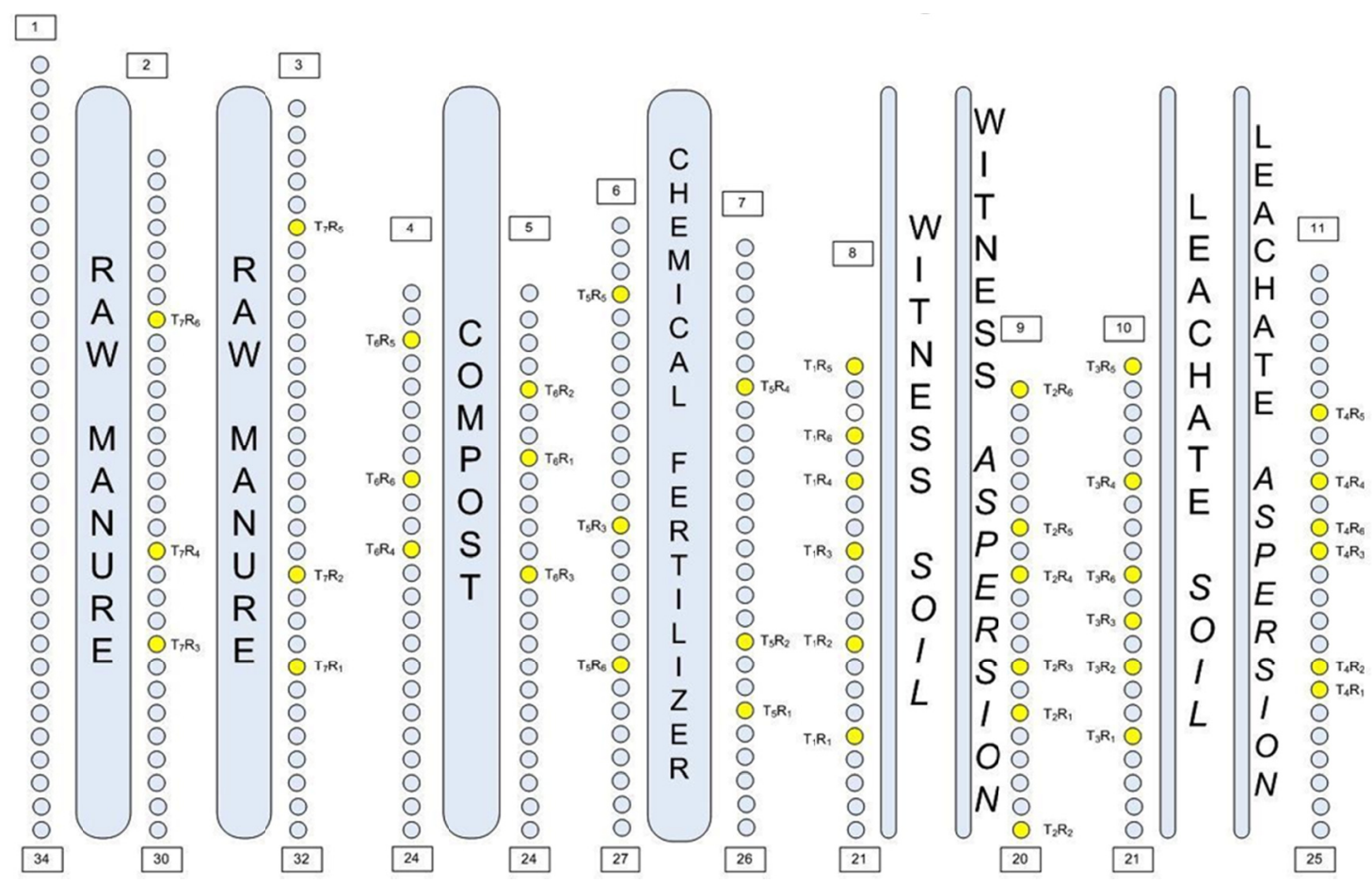

Figure 4. Distribution of rows in the experiment

Source: Self-elaborated with information from the field work log.

\section{Results}

Preliminary results were obtained which showed the physical characteristics of each cladode according to the treatment applied (Table 4).

Table 4. Average values per each cladode according to treatment

\begin{tabular}{llllll}
\hline & Height $(\mathrm{cm})$ & Number of pieces (stalks) & Width & Length & Thickness \\
\hline T1 & 46.36 & 3.07 & 16.21 & 22.32 & 2.65 \\
T2 & 36.00 & 1.86 & 17.36 & 23.54 & 3.06 \\
T3 & 49.58 & 2.92 & 18.83 & 28.75 & 3.27 \\
T4 & 54.33 & 3.42 & 20.50 & 31.63 & 3.53 \\
T5 & 56.17 & 3.92 & 17.17 & 30.63 & 3.50 \\
T6 & 64.25 & 3.50 & 18.83 & 31.21 & 3.38 \\
T7 & 60.80 & 3.67 & 19.88 & 29.75 & 3.37 \\
\hline
\end{tabular}

Source: Self-elaborated with results obtained.

Table 4 shows that in a preliminary test, cladodes fertilized with organic methods (compost, leachate and water) presented a higher volume. Especially the used on compost (Treatment 6) resulted in the higher general height of cladodes.

Subsequently, a laboratory quality analysis was performed. For quality analysis, cladodes were harvested at dawn (7:00 a.m. to 9:00 a.m., 12:00 a.m. to 14:00 p.m.); thorn removal was carried out in field immediately after harvesting and transported in a cooler $\left( \pm 4{ }^{\circ} \mathrm{C}, 90 \mathrm{~min}\right)$ to the laboratory where five cladodes with 10 to $20 \mathrm{~cm}$ of length were selected for each repetition, to which they were determined the color index, shear strength, titratable acidity and $\mathrm{pH}$. The analysis provided the following results: 
Table 5. Quality analysis of cladodes produced with different fertilization sources

\begin{tabular}{lllllll}
\hline \multirow{2}{*}{ Treatment } & $\mathrm{pH}$ & AT $(\%$ Ac. malic) & Texture $(\mathrm{Nw})$ & \multicolumn{3}{c}{ Color } \\
\cline { 4 - 7 } & & & & $\mathrm{L}$ & Chroma & ${ }^{\circ}$ Hue \\
\hline Regular water to soil & $5.1 \mathrm{a}^{\mathrm{z}}$ & $0.92 \mathrm{a}$ & $5.1 \mathrm{c}$ & $33.2 \mathrm{a}$ & $17.1 \mathrm{a}$ & $54.6 \mathrm{a}$ \\
Regular water & $4.9 \mathrm{ab}$ & $0.67 \mathrm{a}$ & $6.8 \mathrm{ab}$ & $32.4 \mathrm{a}$ & $17.6 \mathrm{a}$ & $54.7 \mathrm{a}$ \\
Leached to soil & $4.9 \mathrm{ab}$ & $0.67 \mathrm{a}$ & $5.8 \mathrm{abc}$ & $33.8 \mathrm{a}$ & $16.6 \mathrm{a}$ & $58.4 \mathrm{a}$ \\
Leachate from compost & $4.9 \mathrm{ab}$ & $0.70 \mathrm{a}$ & $5.1 \mathrm{c}$ & $33.1 \mathrm{a}$ & $17.6 \mathrm{a}$ & $53.0 \mathrm{a}$ \\
Chemical fertilizer & $4.8 \mathrm{ab}$ & $0.67 \mathrm{a}$ & $6.9 \mathrm{a}$ & $33.8 \mathrm{a}$ & $17.3 \mathrm{a}$ & $54.6 \mathrm{a}$ \\
Compost & $4.7 \mathrm{~b}$ & $0.72 \mathrm{a}$ & $5.3 \mathrm{abc}$ & $32.0 \mathrm{a}$ & $17.1 \mathrm{a}$ & $54.4 \mathrm{a}$ \\
Fresh cow manure & $4.7 \mathrm{~b}$ & $0.97 \mathrm{a}$ & $5.21 \mathrm{bc}$ & $33.0 \mathrm{a}$ & $17.8 \mathrm{a}$ & $55.2 \mathrm{a}$ \\
\hline
\end{tabular}

Source: Self-elaborated with results of lab analysis.

Table 6. Weight loss and oxidation of cladodes produced with different fertilization sources

\begin{tabular}{llllll}
\hline \multirow{2}{*}{ Treatment } & \multicolumn{3}{c}{ Weight loss } & & \multicolumn{2}{c}{ Oxidation } \\
\cline { 2 - 3 } \cline { 5 - 5 } \cline { 5 - 5 } Regular water to soil & $(\mathrm{g})$ & $(\%)$ & & Regular & Severe \\
Regular water & $13.3 \mathrm{a}^{\mathrm{z}}$ & $15.25 \mathrm{a}$ & & $1.2 \mathrm{c}$ & $4.4 \mathrm{~b}$ \\
Leached to soil & $8.2 \mathrm{ab}$ & $13.6 \mathrm{a}$ & & $2.3 \mathrm{bc}$ & $6.0 \mathrm{ab}$ \\
Leachate from compost & $7.6 \mathrm{~b}$ & $13.8 \mathrm{a}$ & & $2.5 \mathrm{bc}$ & $5.9 \mathrm{ab}$ \\
Chemical fertilizer & $9.1 \mathrm{ab}$ & $10.2 \mathrm{a}$ & & $4.4 \mathrm{ab}$ & $6.4 \mathrm{ab}$ \\
Compost & $8.0 \mathrm{ab}$ & $13.0 \mathrm{a}$ & & $4.6 \mathrm{a}$ & $6.6 \mathrm{a}$ \\
Fresh cow manure & $11.2 \mathrm{ab}$ & $7.4 \mathrm{a}$ & & $1.8 \mathrm{bc}$ & $5.6 \mathrm{ab}$ \\
\hline
\end{tabular}

Source: Self-elaborated with results of lab analysis.

Table 5 and 6 show results obtained with the laboratory analysis. Results show that although the treatments showed no significant effect on the number of cladodes or on the accumulation of fresh and dry weight of both cladodes and plant, a tendency was observed for a greater number of cladodes in those plants fertilized with compost leachate. On the other hand, fresh and dry weights tended to decrease in those cladodes fertilized by compost leachate and, also, greater fresh and dry weight of cladodes tended to occur in plants treated with water only.

In terms of the quality of nopal, treatments had no significant effect on the titratable acidity or on the color parameters (Table 5). Compost and manure treatments significantly reduced the $\mathrm{pH}$ of the cladodes compared to the control treatment (regular water). Regarding the texture of the cladodes, the treatment with synthetic fertilizer resulted in a higher cut resistance than treatments based on manure, leachate and water to the soil (Table 5). Plants fertilized with synthetic fertilizer resulted also in a lower soil moisture content than the rest of the treatments. In terms of shelf-live, although statistical differences $(\mathrm{p}<0.05)$ were found in weight loss recorded in grams in cladodes after seven days of room temperature storage, this weight loss recorded on the basis of initial weight percent did not show statistical differences (Table 6). The cladodes treated with leachate compost and those fertilized with synthetic fertilizer lasted more days on the shelf without showing darkening, although this effect lasted more with the synthetic fertilization.

\section{Discussion}

As reported in the results section, the data obtained after twelve months of observation, allowed measuring impacts of different fertilization method on nopal. Data showed that the use of solid compost (T4) and leachate (T6) resulted in a higher level of productivity compared to yields obtained with raw manure (T7) and synthetic fertilizer (T5). This can also be seen in Figure 5. 


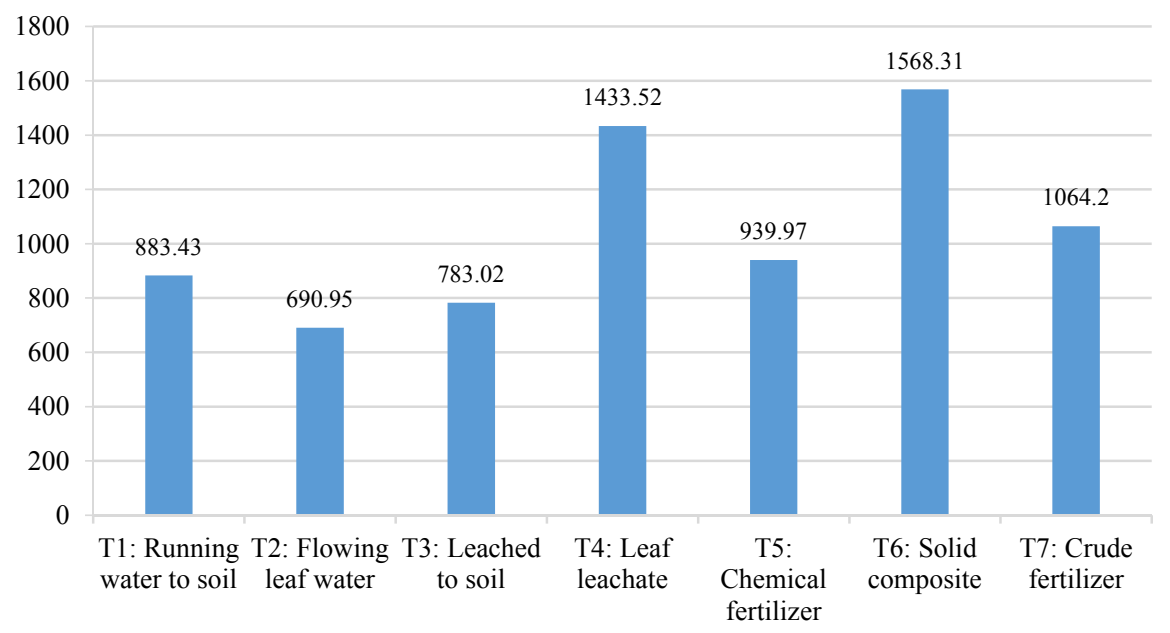

Figure 5. Average yields per plant in kilograms $(\mathrm{Kg})$ per type of treatment

Source: Self-elaborated with results of lab analysis.

Nevertheless, although the results obtained in this research showed that there are positive impacts when using sustainable methods of fertilization. However, in order to encompass the real scope that a fertilization treatment could have not only in a crop but also in an entire agricultural sector, the discussion must involve environmental and economic aspects as a variable to improve agricultural processes.

The use of organic fertilizers implies a greater competitive advantage due to the quality of the product at a competitive price in the market. On the other hand, the substitution of raw manure by the compost involves positive externalities, which favors the environmental impact in the reduction of greenhouse gases (GHG). Often, the climatic impact makes difficult to analyze the advantages of the production process and the final use of compost in open-air crops. Because of this, the use of organic raw materials in plant cultivation using bio-tunnels can help to homogenize the yields by surface type and increase the crop each year. With this, it may be possible to influence the conservation of natural resources since organic fertilizers such as compost are associated with low environmental costs.

The present research responds to the question of which elements foment or preclude the conversion of a traditional agriculture scheme to a sustainable model among the nopal products in the borough of Milpa Alta in Mexico City. It is important to mention that abuse in the use of manure carries environmental risks. The control in the application of the same is a complex process, which if it is not carried out in a proper manner, is translated in damages for the agricultural production. Applying manure at rates that are too low can lead to nutrient deficiency and low yields. On the other hand, a dose too high can lead to nitrate leaching, phosphorus supply, accelerate eutrophication of water bodies, and excessive vegetative growth of some crops (Tavera et al., 2013). The nutrient content in manure varies depending on the type of animal from which it comes, from the packaging, storage and processing it receives. In the literature it is possible to find different tables with nutrient content of different types of manure, experts in the field (Bierman \& Rosen, 2005; Rahman \& Wiederholt, 2001; Harris \& Yusuf, 2001; Shirani et al., 2010; Weill \& McKyes, 1989) strongly recommend that manure must be analyzed by laboratory tests before it can be used to determine the specific characteristics, nutrient content and moisture content of the manure. In that way determine if its use is feasible depending on the crop. A laboratory analysis to determine the nutrient content of manure should provide accurate data on: total nitrogen $(\mathrm{N})$, ammonium $\left(\mathrm{NH}_{4}{ }^{+}\right)$, phosphorus pentoxide $\left(\mathrm{P}_{2} \mathrm{O}_{5}\right)$, and potassium oxide $\left(\mathrm{K}_{2} \mathrm{O}\right)$. The use of excess fresh manure leads to salt accumulation and leach losses, just as fresh manure may contain high amounts of bad grass seed, which can lead to weed problem. In addition, several pathogens such as E. coli may be present in fresh manure and may produce severe gastrointestinal diseases. In addition to the above, the effects caused by the use of manure, has more implications than the safety of the crop. GHG emissions may be an important factor in environmental matters, however, the region (Milpa Alta) currently lacks of controls for monitoring the GHG emissions. Nevertheless, studies have been carried out at the global level where the emission of $\mathrm{CH}_{4}$ generated by manure are estimated in $0.236 \mathrm{~kg} \mathrm{ha}^{-1} \mathrm{D}^{-1}$ (with $95 \%$ confidence index, 0.163-0.332) and where emissions are reported to increase with manure density, $\mathrm{pH}$, temperature and mass (Redding et al., 2015). 
On the other hand, the use of solid and liquid compost has positively impacted the profitability in the production of nopal. The use of compost has not only increased yield per soil area (Figure 4), but also reduced costs (Table 7) (cost per $\mathrm{kg}$ of solid and liquid compost versus chemical fertilizer and raw manure). This result has allowed obtaining a proper, efficient and sustainable cultivation process with the use of organic fertilizers. Therefore, the compost can be commercialized within the current market of nopal with a competitive price.

Table 7. Comparative of prices of raw materials

\begin{tabular}{lll}
\hline Raw Manure & Chemical Fertilizer (Urea) & Organic Fertilizer (Compost) \\
\hline$\$ 4,00 \mathrm{~kg}$ & $\$ 7,40 \mathrm{~kg}$ & $\$ 1,50 \mathrm{~kg}$ \\
\hline
\end{tabular}

Source: Self-Elaborated with information from work-field.

\section{Conclusion}

A model of sustainable agriculture must have the capacity to ensure the correct use of natural resources to guarantee an organic product but without compromising the availability of resources for future generations and above all without negative effects on the environment. The model for organic production of nopal, which uses compost as an organic fertilizer, aims to train producers in aspects related to negative aspects when using agrochemicals. As showed in the results section, the use of compost was proven successful in term of efficient and harmlessness. This would help producers to develop and implement strategies focused on achieving a sustainable development oriented to the conservation of natural resources.

\section{References}

Acosta-Martínez, V., Mikha, M. M., Sistani, K. R., Stahlman, P. W., Benjamin, J. G., Vigil, M. F., \& Erickson, R. (2011). Multi-location study of soil enzyme activities as affected by types and rates of manure application and tillage practices. Agriculture, 1, 4-21. https://doi.org/10.3390/agriculture1010004

Bierman, P. M., \& Rosen, C. J. (2005). Maintaining soil fertility in an organic fruit and vegetable crops system. The College of Food and Environmental Sciences, The University of Minnesota, USA. Retrieved from https:/www.extension.umn.edu/garden/yard-garden/soils/maintaining-soil-fertility-in-an-organic-fruit-andvegetable-crops-system/doc/M1191.pdf

Bunge-Vivier, V. (2008). Performance of rural productive organizations: Influence of social capital on the performance of the processing organizations of nopal of Milpa Alta (Master's thesis, National Autonomous University of Mexico, Mexico). Retrieved from http://132.248.9.195/ptd2008/septiembre/0631925/ Index.html

Chanduví, F. (1993). Irrigation with wastewater in Xochimilco, Mexico City, Mexico. Paper presented at Annals of the Expert Consultation Organized by FAO, Santiago, Chile. Retrieved from http://agris.fao.org/ agris-search/search.do?recordID=XF9543713

Chen, R., Wang, Y., Wei, S., Wang, W., \& Lin, X. (2014). Windrow composting mitigated CH4 emissions: Characterization of methanogenic and methanotrophic communities in manure management. FEMS Microbiol Eco., 90, 575-586. https://doi.org/10.1111/1574-6941.12417

GCDMX (Government of Mexico City). (2013). Statistics and information about Milpa Alta. Government of Mexico City. Retrieved from http://www.milpa-alta.df.gob.mx/index.php/febrero-2013/37-noticias-mes-defebrero-2013/532-milpa-alta-principal-productor-de-nopal-a-nivel-nacional

Harris, F., \& Yusuf, M. A. (2001). Manure Management by Smallholder Farmers in the Kano Close-Settled Zone, Nigeria. Experimental Agriculture, 37, 319-332. https://doi.org/10.1017/S0014479701003040

Hernandez-Cruz, L. M. (2016). Green seal certification as a competitive advantage in cactus production in Mexico City (Master's thesis, National Polytechnic Institute, México). Retrieved from http://tesis.ipn.mx/ bitstream/handle/123456789/22323/HERNANDEZ\%20CRUZ\%20LESLIE\%20MONSERRAT.pdf?sequen ce $=1$ \&isAllowed $=\mathrm{y}$

INECC (National Institute of Ecology and Climate Change). (2009). Nopal Verdura, Opuntia ssp. Alternative Cultivation for the Arid and Semiarian Zones of Mexico. Retrieved from http://www2.inecc.gob.mx/ publicaciones/descarga.html?cv_pub=71\&tipo_file=pdf\&filename=71 
Karami, A., Homaee, M., Afzalinia, S., Ruhipour, H., \& Basirat, S. (2012). Organic resource management: Impacts on soil aggregate stability and other soil physico-chemical properties. Agriculture, Ecosystems and Environment, 148, 22-28. https://doi.org/10.1016/j.agee.2011.10.021

Kariyapperuma, K. A., Furon, A., \& Wagner-Riddle, C. (2012). Non-growing season nitrous oxide fluxes from an agricultural soil affected by application of liquid and composted swine manure. Canadian Journal of Soil Science, 92, 315-327. https://doi.org/10.4141/cjss2011-059

Lynch, D. H., Voroney, R. P., \& Warman, P. R. (2005). Soil Physical properties and organic matter fractions under forages receiving compost, manure or fertilizer. Compost Science \& Utilization, 13, $252-261$. https://doi.org/10.1080/1065657X.2005.10702249

Martínez, F., Casermeiro, M. A., Morales, D., Cuevas, G., \& Walter, I. (2003). Effects on run-off water quantity and quality of urban organic waste applied in a degraded semi-arid ecosystem. The Science of the Total Environment, 305, 13-21. https://doi.org/10.1016/S0048-9697(02)00472-2

Massé, D. I., Croteau, F., Patni, N. K., \& Masse, L. (2003). Methane emissions from dairy cow and swine manure slurries stored at $10{ }^{\circ} \mathrm{C}$ and $15{ }^{\circ} \mathrm{C}$. Canadian Biosystems Engineering, 45, 61-66. https://doi.org/ 10.1111/j.1740-0929.2005.00240.x

Rahman, S., \& Wiederholt, R. (2012). Options for Land Application of Solid Manure. North Dakota State University, USA. Retrieved from https://www.ag.ndsu.edu/publications/livestock/options-for-land-applicati on-of-solid-manure/nm1613.pdf

Redding, M., Devereux, J., Phillips, F., Lewis, R., Naylor, T., Kearton, T., ... Weidemann, S. (2015). Field Measurement of Beef Pen Manure Methane and Nitrous Oxide Reveals a Surprise for Inventory Calculations. Journal of Environmental Quality, 44, 720-728. https://doi.org/10.2134/jeq2014.04.0159

Shirani, H., Hajabbasi, M. A., Afyuni, M., \& Hemmat, A. (2002). Effects of Farmyard Manure and Tillage Systems on Soil Physical Properties and Corn Yield in Central Iran. Soil and Tillage Research, 68, 101-108. https://doi.org/10.1016/S0167-1987(02)00110-1

Tavera, M. E., Escamilla, P., Alvarado, H., Salinas, E., \& Galicia, S. (2014). Regional Development Model Based on Organic Production of Nopal. Modern Economy, 5(3), 239-249. https://doi.org/10.4236/me.2014. 53025

Velasco, D. (2014). Model of Commercialization of Organic Nopal in the Delegation Milpa Alta (Master's thesis, National Polytechnic Institute, México). Retrieved from http://148.204.210.201/tesis/1409766675352 TesisDanielV.pdf

Weill, A. E., \& McKyes, G. (1989). Agronomic and Economic Feasibility of Growing Corn under Reduced Tillage and Inorganic or Organic Fertilizer in Quebec. Soil \& Tillage Research, 14, 311-315. https://doi.org/ 10.1016/0167-1987(89)90052-4

Withers, P. J. A., Neal, C., Jarvie, H. P., \& Doody, D. G. (2014). Agriculture and eutrophication: Where do we go from here? Sustainability, 6, 5853-5875. https://doi.org/10.3390/su6095853

WMO (World Meteorological Organization). (2013). Bulletin on greenhouse gases. Global Atmosphere Watch. Retrieved from https://www.wmo.int/pages/prog/arep/gaw/ghg/documents/GHG_Bulletin_No.9_es.pdf

Zhong, W., Gu, T., Wang, W., Zhang, B., Lin, X., Huang, Q., \& Shen, W. (2010). The effects of mineral fertilizer and organic manure on soil microbial community and diversity. Plant Soil, 326, 511-522. https://doi.org/ 10.1007/s11104-009-9988-y

\section{Copyrights}

Copyright for this article is retained by the author(s), with first publication rights granted to the journal.

This is an open-access article distributed under the terms and conditions of the Creative Commons Attribution license (http://creativecommons.org/licenses/by/4.0/). 